\title{
Calcium levels in maternal milk: relationships with calcium intake during the third trimester of pregnancy
}

\author{
Rosa M. Ortega ${ }^{1}{ }^{*}$, Rosa M. Martínez ${ }^{2}$, M. Elena Quintas ${ }^{1}$, Ana M. López-Sobaler ${ }^{1}$ and Pedro Andrés ${ }^{3}$ \\ ${ }^{1}$ Departamento de Nutrición, Facultad de Farmacia, Universidad Complutense, Madrid, Spain \\ ${ }^{2}$ Servicio de Análisis Clínicos, Servicio de Obstetricia y Ginecología, Hospital INSALUD, Cuenca, Spain \\ ${ }^{3}$ Laboratorio de Técnicas Instrumentales, Facultad de Farmacia, Universidad Complutense, Madrid, Spain
}

(Received 26 November 1996 - Revised 18 November 1997 - Accepted 18 December 1997)

\begin{abstract}
The aim of the present study was to investigate the relationship of $\mathrm{Ca}$ intake and serum $\mathrm{Ca}$ levels during the third trimester of pregnancy with levels of the same mineral in transition milk (days 13-14 of lactation) and mature milk (day 40 of lactation). The study subjects were a group of fifty-seven healthy, lactating mothers aged between 18 and 35 years (mean 27 (SD 3.7) years) whose pregnancies and labour were attended by the Department of Obstetrics and Gynaecology of Cuenca INSALUD Hospital, Spain. Ca intake during the third trimester was determined by recording the consumption of foods over a $5 \mathrm{~d}$ period and by registering Ca provided by dietary supplements. The same method was used to investigate the intake of protein, vitamin $D$, fibre and $\mathrm{Fe}$, nutrients that could affect the use of dietary $\mathrm{Ca}$. Ca levels in maternal serum during this stage of pregnancy, during lactation and in transition and mature milk samples, were determined using 2-cresolphthalein complexone. During pregnancy $70.2 \%$ of subjects showed Ca intakes below $1100 \mathrm{mg} / \mathrm{d}$ (75th percentile). The consumption of Ca supplements was very small and hardly modified the mean quantity supplied by the diet. Subjects with an intake $<1100 \mathrm{mg} / \mathrm{d}$ showed no fall in Ca levels in serum, either during pregnancy or lactation, nor were decreased levels found in transition milk. However, these subjects showed lower Ca levels in mature milk (5.95 (SD 1.56) mmol/l) than did subjects with greater Ca intakes (6.82 (SD 1.31) mmol/l). This may suggest that breast-fed babies of mothers with lower $\mathrm{Ca}$ intakes during pregnancy also receive less $\mathrm{Ca}$.
\end{abstract}

Calcium: Pregnancy: Lactation

Recommendations for $\mathrm{Ca}$ intake during pregnancy and lactation differ around the world, reflecting the inadequacy of knowledge about $\mathrm{Ca}$ requirements in human reproduction (Prentice, 1994).

In theory, insufficient $\mathrm{Ca}$ supply during pregnancy and lactation could result in maternal bone loss, reduced breastmilk $\mathrm{Ca}$ secretion or impaired infant bone development (Prentice, 1994; Prentice et al. 1994; Kalkwarf et al. 1997). However, although $\mathrm{Ca}$ intakes vary widely, no specific problems associated with dietary $\mathrm{Ca}$ deficiency have been identified, Alterations in absorption, metabolism and excretion may conserve $\mathrm{Ca}$ when requirements increase (King \& Weininger, 1991; Prentice, 1994; Repke, 1994; Prentice et al. 1995). Bone changes have been observed during pregnancy and lactation (Prentice, 1994; Gambacciani et al. 1995; Kalkwarf et al. 1997), but their relationship with diet is controversial. Similarly, the effects of maternal $\mathrm{Ca}$ intake on breast-milk $\mathrm{Ca}$ and infant bone growth are not understood (Prentice, 1994).

In order to test the hypothesis that women with greater Ca intakes show higher milk concentrations of this mineral, the relationships between intake and serum levels of $\mathrm{Ca}$ during the third trimester of pregnancy with levels of the same mineral in transition milk (days 13-14 of lactation) and mature milk (day 40 of lactation), were investigated.

\section{Methods}

The study subjects were a group of fifty-seven healthy, pregnant (later lactating) women between 18 and 35 years of age (mean 27 (SD 3.7) years) whose labour was attended by the Department of Obstetrics and Gynaecology at Cuenca INSALUD Hospital, Spain. All subjects volunteered to take part. 
The study protocol was approved by the Comite de Investigación de la Facultad de Farmacia, Universidad Complutense de Madrid and by the Comité Etico del Hospital del INSALUD de Cuenca. At the time of the study (May 1990-March 1991), the annual number of births in Cuenca and its Province was 1400. Of these 400 corresponded to city residents. In order to facilitate contact with subjects during their pregnancies and later during lactation, participants were chosen from the city area. A total of 100 subjects in their third trimester of pregnancy were selected. The criteria for inclusion were that subjects should be free of diabetic disease or pre-eclampsia, be between 18 and 35 years of age, be carrying a single fetus, live in the city area and have declared the desire to breastfeed their baby. After being informed of the characteristics of the study, $82 \%$ accepted the offer to participate. During their third trimester (between weeks 32 and 36) dietary, anthropometric and biochemical studies were made.

After giving birth the study was continued. The composition of subjects' (now lactating mothers) milk was analysed at days 13-14 (transition milk) and 40 (mature milk) (Patton et al. 1990; Institute of Medicine, 1991). A biochemical study of the serum of lactating subjects was also performed at day 40 .

Those subjects with babies of low birth weight $(<2500 \mathrm{~g} ; 4.9 \%$ ) were excluded from the study, as were those who could not continue to provide maternal milk ( $8.5 \%)$. Fourteen subjects were lost from the study because they either moved out of the area, could not be located or lost interest. The final number of subjects was therefore fifty-seven of the eighty-two initially studied. Milk samples were taken between 10.00 and 11.00 hours by manual expression of a $5 \mathrm{ml}$ sample from each breast at the beginning and end of a feed. The experimental details have been described previously by Ortega et al. $(1997 a, b)$.

\section{Dietary survey}

Subjects kept a $5 \mathrm{~d}$ dietary record. Kitchen scales were provided to all subjects in order to facilitate the weighing of food. After the questionnaire was completed, the booklets were returned in person. A qualified nutritionist inspected the records to ensure that they were complete and that sufficient detail had been recorded. In the same interview a food-frequency questionnaire was completed in order to contrast subjects' answers with the results of their $5 \mathrm{~d}$ dietary record and an explanation was requested if answers were inconsistent.

The intakes of $\mathrm{Ca}$ and of other nutrients that might interfere with $\mathrm{Ca}$ use (protein, vitamin $\mathrm{D}$, fibre, $\mathrm{Fe}$ ) were calculated using tables of food composition published by the Instituto de Nutrición (1994).

The intake of supplements was recorded by asking subjects what, and how much, they had taken during their pregnancy. This was then added to the quantity of nutrients provided by the diet.

Estimates of $24 \mathrm{~h}$ energy expenditure were made using equations proposed by the WHO (1985) multiplied by an activity ratio in accordance with the criteria of several expert groups (WHO, 1985; Departamento de Nutrición,
1994) and by adding $1255 \mathrm{~kJ}$ (because subjects were pregnant women; WHO, 1985).

The percentage of discrepancy in reporting was established in accordance with Johnson et al. (1994) using the following formula: (energy expenditure - energy intake) $\times 100 /$ energy expenditure. When this method is used, a negative value indicates a reported energy intake greater than the predicted total energy expenditure (over-reporting) and a positive value denotes a reported energy intake less than the predicted total energy expenditure (under-reporting) (Johnson et al. 1994; Ortega et al. 1996b).

\section{Biochemical study}

Blood samples were taken first thing in the morning from night-fasted subjects. Blood was drawn from the cubital vein and stored in mineral-free, glass vacutainers. Serum $\mathrm{Ca}$ was measured using 2-cresolphthalein complexone (Lorentz, 1982) (CV 3.9\%). Albumin was measured by using dye-binding with bromocresol green after a standard reaction time of $1.5 \mathrm{~min}$ (Rodkey, 1965) (CV 2.1\%). Albumin-corrected $\mathrm{Ca}$ values were established using the formula of Payne et al. (1990): adjusted $\mathrm{Ca}=$ total $\mathrm{Ca}-(0.025 \times$ albumin $)+1$, with $\mathrm{Ca}$ in mmol/1 and albumin in $\mathrm{g} / \mathrm{l}$. Alkaline phosphatase (EC 3.1.3.1) was determined by the phenyl phosphate method (Wootton, 1974) (CV 4.8\%). Breast-milk Ca levels were also measured using 2-cresolphthalein complexone (Lorentz, 1982). Samples were treated according to Laskey et al. (1991). Therefore, before analysis, small portions of wholemilk were lyophilized, subjected to combustion at $500^{\circ}$, and digested with $0.3 \mathrm{M}-\mathrm{HCl}$. The standards were diluted to contain the same concentration of acid as the samples. Before determinations, a quality control check was performed using pooled serum divided into fifty portions. $\mathrm{Ca}$ levels were determined in these fifty samples at a rate of ten per day over five consecutive days. The $\mathrm{CV}$ was then calculated (CV 3.7\%). Accuracy and precision were monitored by including reference material (Reference Bovine Milk Powder, National Bureau of Standards, Gaithersburg, MD, USA), and a portion from a pooled breast-milk sample, with each batch of assays. The methods used were seen to be sufficiently accurate since the values obtained for the controls were within 1 SD of those quoted.

\section{Anthropometric study}

Data were collected in the morning. Weight and height were determined for subjects without shoes and wearing only underwear, using a digital electronic weighing scale (Seca alpha; Rue Lavoisier 91430, Igmy, France; range: $0 \cdot 1-150 \mathrm{~kg}$ ) and a digital stadiometer (Harpenden Pfifter 450; Badem, Padum Aveny, Carlstadt, NJ, USA; range $0.70-2.05 \mathrm{~m})$ respectively. BMI $\left(\mathrm{kg} / \mathrm{m}^{2}\right)$ was calculated from these data. All data were collected by trained personnel following norms set out by WHO (1976).

In order to see how anthropometric values changed over pregnancy, the values of these variables at the beginning of gestation were taken from subjects' clinical records. 
Weight and length of the newborn were measured immediately after birth.

\section{Other data}

The date of each subject's last period plus data from their first ultrasound scan were used to establish the point of gestation. Data such as age, number of children previously borne and use of tobacco were recorded in a questionnaire during the first interview.

\section{Statistical analysis}

Mean values and standard deviations are shown. Where the distribution of results was homogeneous, the degree of significance of differences between means was calculated using the Student's $t$ test. Where the distribution of results was not homogeneous, the Mann-Whitney test was applied. The relationship between dietary and biochemical data plus the relationship between these and the concentration of $\mathrm{Ca}$ in maternal milk was established by calculating the corresponding coefficients for linear correlation. ANOVA was used to investigate the differences in breast-milk $\mathrm{Ca}$ levels and to analyse those of alkaline phosphatase with respect to $\mathrm{Ca}$ intake (25th, 50th, 75th and 100th percentiles). Differences were considered significant if $P<0.05$ (Wonnacott \& Wonnacott, 1977).

\section{Results}

For the presentation of results, subjects were grouped according to whether their $\mathrm{Ca}$ intakes were greater or lower than $1100 \mathrm{mg} / \mathrm{d}$ (75th percentile of the $\mathrm{Ca}$ intake distribution). Table 1 presents both the mothers' and newborns' personal and anthropometric data and shows that there were no differences between the groups for any of the variables recorded.

The percentage of discrepancy in reporting was positive (9.9 (SD 16.9)\%) and no significant differences were observed between women with $\mathrm{Ca}$ intakes below $1100 \mathrm{mg} / \mathrm{d}$ and those with $\mathrm{Ca}$ intakes $\geq 1100 \mathrm{mg} / \mathrm{d}$.

Taking into account the criterion of Goldberg et al. (1991) for the evaluation of energy intake data, energy intake was expressed as a multiple of estimated BMR. The value obtained was 1.23 (SD 0.24). No significant differences were seen between women with $\mathrm{Ca}$ intakes below $1100 \mathrm{mg} / \mathrm{d}(1.2$ (SD 0.2$)$ and those with $\mathrm{Ca}$ intakes $\geq 1100 \mathrm{mg} / \mathrm{d}(1.3(\mathrm{SD} 0.2))$.

$\mathrm{Ca}$ intake was lower than $1100 \mathrm{mg} / \mathrm{d}$ in $70.2 \%$ of subjects. The consumption of supplements was very small and hardly modified the dietary mean when taken into account (Table 2).

An adequate intake of vitamin $D$ is of fundamental importance in the improvement of the use of dietary $\mathrm{Ca}$ (Seely et al. 1997). However, high intakes of protein (Hagsted \& Linkswiler, 1981), Fe (Repke, 1994) or fibre (Frolich, 1995) can interfere with $\mathrm{Ca}$ absorption. The intakes of protein, vitamin $\mathrm{D}$, fibre and Fe (dietary and supplementary), which can alter the use of dietary $\mathrm{Ca}$, were therefore recorded (Table 2). The only differences between the groups were those of protein and fibre intakes which were significantly higher in pregnant subjects with $\mathrm{Ca}$ levels $\geq 1100 \mathrm{mg} / \mathrm{d}$ (Table 2 ).

With respect to the results obtained for serum and milk, it can be seen that the only significant difference between groups was the $\mathrm{Ca}$ content of mature milk which was greater in subjects with higher $\mathrm{Ca}$ intakes (Table 3). A relationship was found between transition and mature milk Ca levels $(r$ 0.4876). When $\mathrm{Ca}$ intake rose from below the 25th percentile in the third trimester $(712 \mathrm{mg} / \mathrm{d})$ to between the 25 th and 50 th percentiles $(712-880 \mathrm{mg} / \mathrm{d})$, the 50 th and

Table 1. Personal and anthropometric data for subjects and their newborns

(Mean values and standard deviations)

\begin{tabular}{|c|c|c|c|c|}
\hline & \multicolumn{2}{|c|}{ Calcium intake $<1100 \mathrm{mg} / \mathrm{d}^{*}$} & \multicolumn{2}{|c|}{ Calcium intake $\geq 1100 \mathrm{mg} / \mathrm{d}^{\star}$} \\
\hline & Mean & SD & Mean & SD \\
\hline $\begin{array}{l}n \\
\text { Age (years) }\end{array}$ & $27 \cdot 2$ & 3.6 & 28.2 & 4.2 \\
\hline $\begin{array}{l}\text { Initial anthropometric data } \\
\text { Weight }(\mathrm{kg}) \\
\text { Height }(\mathrm{m}) \\
\text { BMI }\left(\mathrm{kg} / \mathrm{m}^{2}\right)\end{array}$ & $\begin{array}{c}56.0 \\
1.60 \\
21.8\end{array}$ & $\begin{array}{l}6.1 \\
0.06 \\
2.1\end{array}$ & $\begin{array}{c}60.1 \\
1.61 \\
22.3\end{array}$ & $\begin{array}{c}11.7 \\
0.06 \\
2.5\end{array}$ \\
\hline $\begin{array}{l}\text { Anthropometric data in 3rd trimester } \\
\text { Weight }(\mathrm{kg}) \\
\text { Height }(\mathrm{m}) \\
\text { BMI }\left(\mathrm{kg} / \mathrm{m}^{2}\right)\end{array}$ & $\begin{array}{c}64.9 \\
1.60 \\
25.2\end{array}$ & $\begin{array}{l}6.5 \\
0.05 \\
2.3\end{array}$ & $\begin{array}{c}68.4 \\
1.61 \\
25.5\end{array}$ & $\begin{array}{c}11.1 \\
0.05 \\
2.7\end{array}$ \\
\hline $\begin{array}{l}\text { Weight gain in first two trimesters }(\mathrm{kg}) \\
\text { No. of children previously borne } \\
\text { Length of pregnancy (weeks) } \\
\text { Weight of newborn }(\mathrm{g}) \\
\text { Length of newborn }(\mathrm{m})\end{array}$ & $\begin{array}{c}8.9 \\
0.61 \\
39 \cdot 2 \\
3289.0 \\
0.501\end{array}$ & $\begin{array}{c}2.9 \\
0.68 \\
1.1 \\
396.7 \\
0.014\end{array}$ & $\begin{array}{c}7.7 \\
0.53 \\
39.8 \\
3315.3 \\
0.500\end{array}$ & $\begin{array}{c}2.2 \\
0.74 \\
1.0 \\
426.4 \\
0.016\end{array}$ \\
\hline $\begin{array}{l}\text { Smokers (\%) } \\
\text { No. of cigarettes/d }\end{array}$ & $2 \cdot 3$ & $4 \cdot 3$ & 1.1 & $2 \cdot 4$ \\
\hline Takers of $\mathrm{Ca}$ supplements (\%) & & & & \\
\hline
\end{tabular}

$* 1100 \mathrm{mg} \mathrm{Ca} / \mathrm{d}$ is the 75 th percentile of Ca intake for study subjects. 
Table 2. Calcium intake during the third trimester of pregnancy in fifty-seven women (Mean values and standard deviations)

\begin{tabular}{|c|c|c|c|c|}
\hline & \multicolumn{2}{|c|}{ Calcium intake $<1100 \mathrm{mg} / \mathrm{d} \dagger(n 40)$} & \multicolumn{2}{|c|}{ Calcium intake $\geq 1100 \mathrm{mg} / \mathrm{d}+(n$ 17) } \\
\hline & Mean & SD & Mean & SD \\
\hline Ca supplied by supplements (mg/d) & 0.31 & 1.93 & 6.08 & 23.55 \\
\hline Ca supplied by supplements + diet (mg/d) & 778.8 & 168.5 & $1545 \cdot 0^{*}$ & 677.0 \\
\hline Ca density $(\mathrm{mg} / 4.2 \mathrm{MJ})$ & 380.2 & $104 \cdot 7$ & $630 \cdot 6^{*}$ & $248 \cdot 2$ \\
\hline \multicolumn{5}{|l|}{ Provision by supplements + diet of: } \\
\hline Protein $(g / d)$ & $82 \cdot 1$ & 12.4 & $111.5^{\star}$ & $27 \cdot 9$ \\
\hline Vitamin $\mathrm{D}(\mu \mathrm{g} / \mathrm{d})$ & 5.8 & 11.8 & 7.0 & 9.2 \\
\hline Fibre $(g / d)$ & $17 \cdot 2$ & 5.4 & $20.3^{*}$ & 4.3 \\
\hline $\mathrm{Fe}(\mathrm{mg} / \mathrm{d})$ & 61.7 & 85.5 & 33.6 & 54.8 \\
\hline
\end{tabular}

Mean values were significantly different from those for the low-Ca group, ${ }^{*} P<0.05$.

$+1100 \mathrm{mg} \mathrm{Ca} / \mathrm{d}$ is the 75 th percentile of $\mathrm{Ca}$ intake for study subjects.

Table 3. Levels of calcium in maternal serum during the third trimester, in lactation (day 40) and in transition (days 13--14) and mature milk (day 40) in fifty-seven women

(Mean values and standard deviations)

\begin{tabular}{|c|c|c|c|c|}
\hline & \multicolumn{2}{|c|}{ Calcium intake $<1100 \mathrm{mg} / \mathrm{d} \dagger(n 40)$} & \multicolumn{2}{|c|}{ Calcium intake $\geq 1100 \mathrm{mg} / \mathrm{d} \dagger(n 17)$} \\
\hline & Mean & SD & Mean & SD \\
\hline $\begin{array}{l}\text { Serum data, third trimester of pregnancy } \\
\text { Serum albumin }(\mathrm{g} / \mathrm{l}) \\
\text { Serum Ca (mmol/l) } \\
\text { Albumin-corrected Ca values (mmol/l) } \\
\text { Alkaline phosphatase }(\mathrm{U} / \mathrm{l})\end{array}$ & $\begin{array}{c}3.6 \\
2.21 \\
3.12 \\
169.5\end{array}$ & $\begin{array}{l}0.2 \\
0.11 \\
0.12 \\
51.1\end{array}$ & $\begin{array}{c}3.7 \\
2.23 \\
3.13 \\
157.2\end{array}$ & $\begin{array}{l}0.2 \\
0.13 \\
0.12 \\
59.6\end{array}$ \\
\hline $\begin{array}{l}\text { Serum data, lactation } \\
\text { Serum albumin }(\mathrm{g} / \mathrm{l}) \\
\text { Serum Ca (mmol/l) } \\
\text { Albumin-corrected Ca values (mmol/l) } \\
\text { Alkaline phosphatase }(\mathrm{U} / \mathrm{l})\end{array}$ & $\begin{array}{c}3.9 \\
2.36 \\
3.32 \\
167.3\end{array}$ & $\begin{array}{c}0.3 \\
0.12 \\
0.10 \\
34.8\end{array}$ & $\begin{array}{c}4.0 \\
2 \cdot 42 \\
3 \cdot 30 \\
113 \cdot 3^{*}\end{array}$ & $\begin{array}{c}0.2 \\
0.14 \\
0.12 \\
11.7\end{array}$ \\
\hline $\begin{array}{l}\text { Ca in milk } \\
\text { Transition }(\mathrm{mmol} / \mathrm{l}) \\
\text { Mature }(\mathrm{mmol} / \mathrm{l})\end{array}$ & $\begin{array}{l}6.44 \\
5.95\end{array}$ & $\begin{array}{l}2.20 \\
1.56\end{array}$ & $\begin{array}{l}6.37 \\
6.82^{*}\end{array}$ & $\begin{array}{l}1.96 \\
1.31\end{array}$ \\
\hline
\end{tabular}

Mean values were significantly different from those for the low-Ca group, ${ }^{*} P<0.05$.

$+1100 \mathrm{mg} \mathrm{Ca} / \mathrm{d}$ is the 75 th percentile of $\mathrm{Ca}$ intake for study subjects.

the 75 th $(880-1100 \mathrm{mg} / \mathrm{d})$, or even higher $(1100 \mathrm{mg} / \mathrm{d})$, mature milk Ca levels changed from 5.7 (SD 1.2) $\mathrm{mmol} / 1$ to 6.4 (SD 1.6) $\mathrm{mmol} / \mathrm{l}, 5.2$ (SD 1.3) $\mathrm{mmol} / \mathrm{l}$, and 6.8 (SD 1.3) mmol/l respectively (Fig. 1). When ANOVA was used to analyse milk $\mathrm{Ca}$ levels with respect to $\mathrm{Ca}$ intake, an almost significant difference $(P<0.1)$ was found. The correlation coefficient for $\mathrm{Ca}$ intake and milk $\mathrm{Ca}$ levels was not significant.

No significant differences were found for alkaline phosphatase between pregnant subjects with $\mathrm{Ca}$ intakes greater than or below $1100 \mathrm{mg} / \mathrm{d}$, although there was a tendency to register higher levels in pregnant subjects with lower $\mathrm{Ca}$ intakes. However, in lactating mothers, a significant difference was found for the levels of this enzyme between subjects who, during their pregnancies, took $<1100 \mathrm{mg} \mathrm{Ca} / \mathrm{d}$, and those with higher intakes $(P<0.05$; Table 3$)$. When $\mathrm{Ca}$ intake rose from below the 25th percentile to between the 25th and 50th, 50th and 75 th, or higher, the alkaline phosphatase values recorded were 169.4 (SD 20.6) U/1, 156.0 (SD 37.2) U/1, 182.3 (SD 31) $U / 1$ and $113.3 \mathrm{U} / \mathrm{l}$ respectively. ANOVA of alkaline

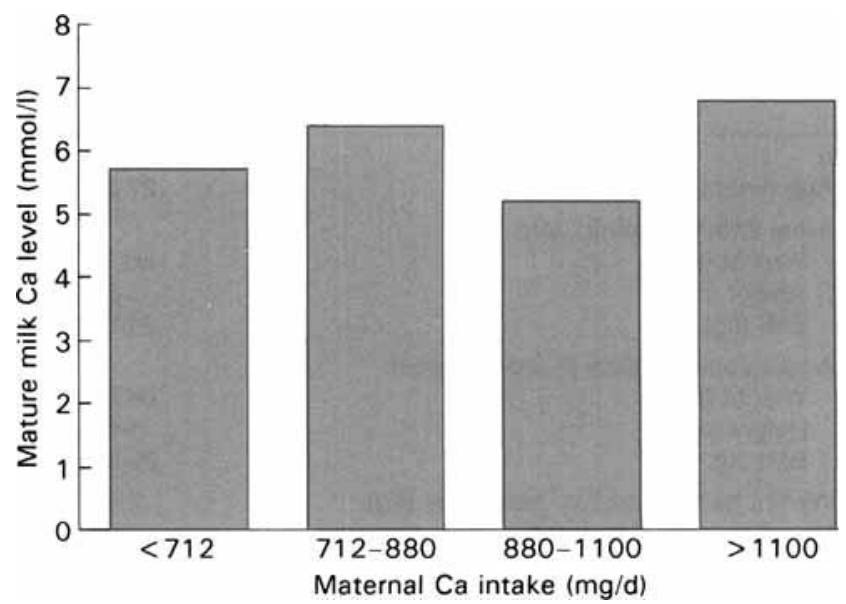

Fig. 1. Change in mature milk calcium levels with respect to calcium intake in the third trimester of pregnancy, from below the 25th percentile $(712 \mathrm{mg} / \mathrm{d})$ to between the 25 th and 50th percentiles $(712-880 \mathrm{mg} / \mathrm{d})$, the 50 th and the 75 th percentiles $(880-1100$ $\mathrm{mg} / \mathrm{d})$, or higher $(>1100 \mathrm{mg} / \mathrm{d})$. 
phosphatase levels with respect to $\mathrm{Ca}$ intake showed a significant difference $(P<0.05)$. The correlation coefficient for the relationship between breast-milk $\mathrm{Ca}$ levels and alkaline phosphatase was significant, both for transition ( $r$ $-0.3337)$, and mature milk $(r-0.4129)$.

\section{Discussion}

The duration of pregnancy and the anthropometric data for the mothers and their newborns (Table 1) were similar to those reported in other studies (Ortega et al. 1994, 1996a; Ash, 1995).

Since energy intake expressed as a multiple of estimated BMR (Goldberg et al. 1991) was low (1.23 (SD 0.24)), and the percentage of discrepancy between energy intake and energy expenditure (Johnson et al. 1994; Ortega et al. $1996 b$ ) was positive, subjects were probably guilty of under-reporting. Nevertheless, the WHO (1985) data are based on weight gains of $12.5 \mathrm{~kg}$ during pregnancy, whereas the pregnant women of the present study showed a weight gain of only 8.8 (SD 2.8) $\mathrm{kg}$ in the first two trimesters. They also declared that they had considerably diminished their physical activity during pregnancy. It is, therefore, possible that the energy output of these subjects was lower than that established by the WHO (1985). But even if there was some degree of underestimation, there were still no differences in the percentage of discrepancy between energy intake and energy expenditure between women with $\mathrm{Ca}$ intakes below $1100 \mathrm{mg} / \mathrm{d}$ (75th percentile of the $\mathrm{Ca}$ intake distribution) and those with $\mathrm{Ca}$ intakes $\geq 1100 \mathrm{mg} / \mathrm{d}$

$\mathrm{Ca}$ intake was lower than that reported in other studies (1009 (SD 336) $\mathrm{mg} / \mathrm{d}$ in pregnant women in Guadalajara, Ortega et al. 1994; 1002 (SD 324) $\mathrm{mg} / \mathrm{d}$ in pregnant women with serum cholesterol $<7.55 \mathrm{mmol} / 1$ and 1030 (SD 363) $\mathrm{mg} / \mathrm{d}$ in similar subjects with higher cholesterol levels, Ortega et al. 1996b). However, the intake recorded in the present study was similar to that reported by Haste $e t$ al. (1991) (840 (SD 37) $\mathrm{mg} / \mathrm{d}$ in pregnant smokers and 990 (SD 32) $\mathrm{mg} / \mathrm{d}$ in pregnant non-smokers) and by Borrud et al. (1993) $(963 \mathrm{mg} / \mathrm{d}, 500 \mathrm{mg} / 4.2 \mathrm{MJ})$, and much greater than that observed by Prentice et al. (1995) in populations of The Gambia $(283 \mathrm{mg} / \mathrm{d})$.

The consumption of $\mathrm{Ca}$ supplements was very low (Table 2), and lower than that of another Spanish population (Guadalajara) investigated by Ortega et al. (1994). In that population, $71 \%$ of subjects showed lower than recommended $\mathrm{Ca}$ intakes if $\mathrm{Ca}$ supplements were ignored. However, if these were included, this value fell to $52 \%$.

Transition and mature milk Ca levels (Table 3 ) were similar to those observed in other studies (Fransson \& Lonnerdal, 1984; Neville et al. 1984; Committee on Nutrition, 1985; Harzer et al. 1986; Butte et al. 1987; Prentice \& Barclay, 1991; Dagnelie et al. 1992; Garza et al. 1993; Prentice, 1994; Prentice et al. 1995; Itriago et al. 1997). No significant differences were seen in the Ca levels of transition and mature milk. These results are in agreement with those of Yoneyama et al. (1995) and
Harzer et al. (1986) who indicate that Ca concentration remains steady during the first five months of lactation.

Some studies have found no accompanying increase in milk $\mathrm{Ca}$ when $\mathrm{Ca}$ intake has been increased (Feeley et al. 1983; Butte et al. 1987; Karra et al. 1987; Institute of Medicine, 1991; Garza et al. 1993; Prentice et al. 1995; Kalkwarf et al. 1997). Others, however, have shown the existence of low milk Ca concentrations in parts of the world where Ca consumption is low (Laskey et al. 1990; Prentice \& Barclay, 1991; Prentice, 1994; Prentice et al. 1994; Yoneyama et al. 1994).

In the present study, greater $\mathrm{Ca}$ concentrations were found in the milk of subjects who, during pregnancy, had $\mathrm{Ca}$ intakes above the 75 th percentile $(1100 \mathrm{mg} / \mathrm{d})$. The results agree with those of Yoneyama et al. (1994) who indicated that a lower frequency of dairy milk intake, or no intake at all, appeared to affect the Ca content of maternal milk.

Similarly, Laskey et al. (1990), who compared the Ca content of the milk of women from The Gambia with that of British women, recorded that the former showed lower $\mathrm{Ca}$ concentrations throughout lactation. Taking into account the amount of milk imbibed by each child per day, these authors showed that the total $\mathrm{Ca}$ intake of Gambian children was also inferior.

Prentice et al. (1995) found Ca supplementation to have no effect on breast milk $\mathrm{Ca}$ concentration. However, these authors studied Gambian women with very low $\mathrm{Ca}$ intakes $(283 \mathrm{mg} / \mathrm{d}$; even with supplementation the value is still low at $714 \mathrm{mg} / \mathrm{d}$ ). Further, there may be differences in $\mathrm{Ca}$ utilization between races (DeSimone et al. 1989). Although these authors indicate that in women with low $\mathrm{Ca}$ intakes, physiological mechanisms operate to furnish $\mathrm{Ca}$ for breastmilk production, the limits of this capability have not been established. Neither has the minimum tolerable $\mathrm{Ca}$ intake been clearly established, and whether it is the same in all races, nor has the optimum level for the protection of mother and newborn (either during pregnancy or lactation) been determined.

In disagreement with Chan (1982), and Moser \& Reynolds (1983), no relationship was found between maternal serum Ca levels and those of milk. In accordance with Neville et al. (1984), Butte et al. (1987), and Prentice \& Barclay (1991), the number of children previously borne was found to have no influence on milk $\mathrm{Ca}$ levels. As reported by Butte et al. (1987), no relationship was found between milk $\mathrm{Ca}$ levels and maternal anthropometric variables.

Although subjects with $\mathrm{Ca}$ intakes $\geq 1100 \mathrm{mg} / \mathrm{d}$ also showed greater intakes of fibre and protein, which could reduce absorption of the mineral (Hagsted \& Linkswiler, 1981; Frolich, 1995), their mature milk Ca levels were higher compared with those who took $<1100 \mathrm{mg} / \mathrm{d}$ during pregnancy.

Marya et al. (1981) found elevated levels of alkaline phosphatase in lactating subjects. This was taken to indicate a deterioration of subjects' bone. These authors showed that the elevation of enzyme level was significantly lower in women with milk intakes of more than 0.5 litres per $\mathrm{d}$. Bearing in mind that in the lactating mothers of the present study a significant difference was found for the 
levels of this enzyme between subjects who, during their pregnancies, took $<1100 \mathrm{mg} \mathrm{Ca} / \mathrm{d}$ and those with higher intakes $(P<0.05$; Table 3$)$, these results may indicate bone deterioration in subjects with low $\mathrm{Ca}$ intakes during pregnancy. The existence of significant, inverse correlations between alkaline phosphatase and transition and mature milk $\mathrm{Ca}$ levels, and the fact that it is subjects with $\mathrm{Ca}$ intakes of $\geq 1100 \mathrm{mg} / \mathrm{d}$ who show the highest milk Ca levels and lowest alkaline phosphatase levels, may indicate that higher intakes of $\mathrm{Ca}$ provide better bone protection and lead to higher milk $\mathrm{Ca}$ levels.

\section{Acknowledgement}

This work was supported by the Fondo de Investigaciones Sanitarias de la Seguridad Social (FISss) (España).

\section{References}

Ash S (1995) Dietary intakes of pregnant women in Sydney, New South Wales. Australian Journal of Nutrition and Dietetics 52, $149-153$.

Borrud LG, Krebs-Smith SM, Friedman L \& Guenther PM (1993) Food and nutrient intakes of pregnant and lactating women in the United States. Journal of Nutrition Education 25, 176-185.

Butte NF, Garza C, O’Brian E, Wills C \& Nichols BL (1987) Macro- and trace-mineral intakes of exclusively breast-fed infants. American Journal of Clinical Nutrition 45, 42-48.

Chan GM (1982) Human milk calcium and phosphate levels of mothers delivering term and preterm infants. Journal of Pediatric Gastroenterology and Nutrition 1, 201-205.

Committee on Nutrition (1985) Composition of human milk: normative data. In Pediatric Nutrition Handbook, pp. 363-368. Illinois: American Academy of Pediatrics.

Dagnelie PC, van Staveren WA, Roos AH, Tuinstra LG \& Burema J (1992) Nutrients and contaminants in human milk from mothers on macrobiotic and omnivorous diets. European Journal of Clinical Nutrition 46, 355-366.

Departamento de Nutrición (1994) Ingestas Recomendadas de Energía y Nutrientes para la Población Española (Tables of Recommended Intakes of Energy and Nutrients for the Spanish Population). Madrid: Departamento de Nutrición.

DeSimone DP, Stevens J, Edwards J, Shary J, Gordon L \& Bell NH (1989) Influence of body habitus and race on bone mineral density of the mid-radius, hip and spine in aging women Journal of Bone and Mineral Research 4, 827-830.

Feeley RM, Eitenmiller RR, Jones JB Jr \& Barnhart H (1983) Calcium, phosphorus and magnesium contents of human milk during early lactation. Journal of Pediatric Gastroenterology and Nutrition 2, 262-267.

Fransson GB \& Lönnerdal B (1984) Iron, copper, zinc, calcium, and magnesium in human milk fat. American Journal of Clinical Nutrition 39, 185-189.

Frolich W (1995) Bioavailability of micronutrients in a fibre-rich diet, especially related to minerals. European Journal of Clinical Nutrition 49, 116-122.

Gambacciani M, Spinetti A, Gallo R, Cappagli B, Teti GC \& Facchini V (1995) Ultrasonographic bone characteristics during normal pregnancy: longitudinal and cross-sectional evaluation. American Journal of Obstetrics and Gynecology 173, 890-893.

Garza C, Butte NF \& Goldman AS (1993) In Textbook of Pediatric Nutrition, 2nd ed., [RM Suskind and L LewinterSuskind, editors]. New York, NY: Raven Press Ltd.
Goldberg GR, Black AE, Jebb SA, Cole JJ, Murgatroyd PR, Coward WA \& Prentice AM (1991) Critical evaluation of energy intake data using fundamental principles of energy physiology: 1. Derivation of cut-off limits to identify underrecording. European Journal of Clinical Nutrition 45, 569581.

Hagsted M \& Linkswiler HM (1981) Long-term effects of protein intake on calcium metabolism in young adult women. Journal of Nutrition 111, 244-251.

Harzer G, Haug M \& Bindels JG (1986) Biochemistry of maternal milk in early lactation. Human Nutrition: Applied Nutrition 40, 11-18.

Haste FM, Brooke OG, Anderson HR \& Bland JM (1991) The effect of nutritional intake on outcome of pregnancy in smokers and non-smokers. British Journal of Nutrition 65, 347-354.

Institute of Medicine (1991) Nutrition During Lactation, pp. 57219. Washington, DC: National Academy Press.

Instituto de Nutrición (1994) Tablas de Composición de Alimentos Españoles (Spanish Food Composition Tables). Madrid: Instituto de Nutrición.

Itriago A, Carrión N, Fernández A, Puig M \& Dini E (1997) Contenido de zinc, cobre, hierro, calcio, fósforo y magnesio en leche materna en los primeros días de lactación (Content of zinc, copper, iron, calcium, phosphorus and magnesium in maternal milk during the early days of lactation). Archivos Latinoamericanos de Nutrición 47, 14-22.

Johnson RK, Goran MI \& Pohlman ET (1994) Correlates of overand underreporting of energy intake in healthy older men and women. American Journal of Clinical Nutrition 59, 12861290.

Kalkwarf HJ, Specker BL, Bianchi DC, Ranz J \& Ho M (1997) The effect of calcium supplementation on bone density during lactation and after weaning. New England Journal of Medicine 337, 523-528.

Karra MV, Kirksey A, Gala O, Bassily NS, Harrison GG \& Jerome NW (1988) Zinc, calcium and magnesium concentrations in milk from American and Egyptian women throughout the first 6 months of lactation. American Journal of Clinical Nutrition 47, 642-648.

King JC \& Weininger J (1991) Embarazo y lactancia (Pregnancy and lactation). In Conocimientos Actuales Sobre Nutrición (Present Nutrition Knowledge), pp. 362-369. Washington, DC: ILSI-North America.

Laskey MA, Dibba B \& Prentice A (1991) A semi-automated micromethod for the determination of calcium and phosphorus in human milk. Annals of Clinical Biochemistry 28, 49-54.

Laskey MA, Prentice A, Shaw J, Zachou T \& Ceesay SM (1990) Breast-milk calcium concentrations during prolonged lactation in British and rural Gambian mothers. Acta Paediatrica Scandinavica 79, 507-512.

Lorentz K (1982) Improved determination of serum Ca with 2cresolphthalein complexone. Clinica Chimica Acta 126, 327334.

Marya RK, Rathee S \& Arora SR (1981) Concentrations of calcium, inorganic phosphorus and alkaline phosphatase in the sera of lactating women in north India. Annals of Nutrition and Metabolism 25, 59-64.

Moser PB \& Reynolds RD (1983) Dietary zinc intake and zinc concentrations of plasma, erythrocytes and breast milk in antepartum and postpartum lactating and nonlactating women: a longitudinal study. American Journal of Clinical Nutrition 38, 101-108.

Neville MC, Keller RP, Seacat J, Casey CE, Allen JC \& Archer $P$ (1984) Studies on human lactation. I. Within-feed and between-breast variation in selected components of human milk. American Journal of Clinical Nutrition 40, 635646. 
Ortega RM, Andrés P, Martínez RM \& López-Sobaler AM (1997a) Vitamin A status during the third trimester of pregnancy: influence on concentrations of vitamin $A$ in maternal milk. American Journal of Clinical Nutrition 66, 564-568.

Ortega RM, Andrés P, Martínez RM, López-Sobaler AM \& Quintas E (1997b) Zinc levels in maternal milk: the influence of nutritional status with respect to zinc during the third trimester of pregnancy. European Journal of Clinical Nutrition 51, 253258.

Ortega RM, Gaspar MJ \& Cantero M (1996a) Relationship between lipid parameters quantified in maternal and cord blood in two Spanish groups. International Journal of Vitamin and Nutrition Research 66, 250-257.

Ortega RM, Gaspar MJ \& Moreiras O (1994) Dietary assessment of a pregnant Spanish women group. International Journal of Vitamin and Nutrition Research 64, 130-134.

Ortega RM, Requejo AM, Quintas ME, Sánchez-Quiles B, LópezSobaler AM \& Andrés P (1996b) Estimated energy balance in female university students: differences with respect to body mass index and concern about body weight. International Journal of Obesity 20, 1127-1129.

Patton S, Canfield LM, Huston GE, Ferris AM \& Jensen RG (1990) Carotenoids of human colostrum. Lipids 25, 159 165.

Payne RB, Little AJ \& Evans RT (1990) Albumin-adjusted calcium concentration in serum increases during normal pregnancy. Clinical Chemistry 36, 142-144.

Prentice A (1994) Maternal calcium requirements during pregnancy and lactation. American Journal of Clinical Nutrition 59, 477S-482S.

Prentice A \& Barclay DV (1991) Breast milk calcium and phosphorus concentrations of mothers in rural Zaire. European Journal of Clinical Nutrition 45, 611-617.
Prentice A, Dibba B, Jarjou LMA, Laskey MA \& Paul AA (1994) Is breast milk calcium concentration influenced by calcium intake during pregnancy? Lancet 344, 411-412.

Prentice A, Jarjou LMA, Cole TJ, Stirling DM, Dibba B \& Fairweather-Tait, S (1995) Calcium requirements of lactating Gambian mothers: effects of a calcium supplement on breastmilk calcium concentration, maternal bone mineral content, and urinary calcium excretion. American Journal of Clinical Nutrition 62, 58-67.

Repke JT (1994) Calcium and vitamin D. Clinical Obstetrics and Gynaecology 37, 550-557.

Rodkey FL (1965) Direct spectrophotometric determination of albumin in human serum. Clinical Chemistry 2, 478-487.

Seely EW, Brown EM, DeMaggio DM, Weldon DK \& Graves SW (1997) A prospective study of calciotropic hormones in pregnancy and post partum: reciprocal changes in serum intact parathyroid hormone and 1,25-dihydroxyvitamin D. American Journal of Obstetrics and Gynecology 176, 214-217.

Wonnacott HW \& Wonnacott RJ (1977) Introductory Statistics. New York, NY: John Wiley and Sons, Inc.

Wootton IDP (1974) Microanalysis in Medical Biochemistry, p. 104. London: Churchill Livingstone.

World Health Organization (1976) Methodology of Nutritional Surveillance. Technical Report Series no. 53, p. 20. Geneva: WHO.

World Health Organization (1985) Energy and Protein Requirements. Technical Report Series no. 724, pp. 71-80. Geneva: WHO.

Yoneyama K, Goto I \& Nagata H (1995) Changes in the concentrations of nutrient components of human milk during lactation. Nippon Koshu Eisei Zasshi 42, 472-481.

Yoneyama K, Goto I, Nagata H \& Ikeda J (1994) Effects of maternal food intake on the total protein, fat, lactose and calcium concentrations in human milk. Nippon Koshu Eisei Zasshi 41, 507-517. 